\title{
Challenges in Performance Evaluation System of Prosecutors ${ }^{1}$
}

\author{
Goran Ilic'2 \\ Marina Matic' Boškovic'3
}

\section{ABSTRACT}

A series of reforms adopted over the last decade reflect different views of how the judicial system, and particularly the prosecutors, should be managed. In 2000, democratic changes were followed by judicial reform initiatives, set as one of the priorities of the Government at that time. Many of those reform activities are connected with EU integration process and fulfilment of EU and Council of Europe standards related to the judiciary. Approach, methodology and timeframe of judiciary reforms are set in the two five year strategic documents; first covered period 2006-2011 and second is for period 2013-2018. National Judicial Reform Strategy 2013-2018 set following goals: independence, impartiality and quality, competence, accountability and efficiency. Both strategic documents define set of measures and indicators to improve efficiency and competence of justice system as whole and efficiency and competence of judges and prosecutors as holders of judicial functions. Debate on results of reform activities is still ongoing in professional public.

Key words: Evaluation System of Prosecutors. Efficiency.

1 Received in: 20/06/2017. Approved in: 21/06/2017. IAP Annual Conference, Dubai, 26 November 2014. 2 President of Association of Public Prosecutors and Deputy Public Prosecutors of Serbia and Deputy of Republic Public Prosecutor. E-mail: office@uts.org.rs

3 Vice-president of the Program Council of the Association of public prosecutors and deputy public prosecutors of Serbia. E-mail: marina.matic@uts.org.rs 


\section{REFORM ACTIVITIES}

A series of reforms adopted over the last decade reflect different views of how the judicial system, and particularly the prosecutors, should be managed. In 2000, democratic changes were followed by judicial reform initiatives, set as one of the priorities of the Government at that time. Many of those reform activities are connected with EU integration process and fulfilment of EU and Council of Europe standards related to the judiciary.

Approach, methodology and timeframe of judiciary reforms are set in the two five year strategic documents; first covered period 2006-2011 and second is for period 2013-2018. National Judicial Reform Strategy 2013-2018 set following goals: independence, impartiality and quality, competence, accountability and efficiency.

Both strategic documents define set of measures and indicators to improve efficiency and competence of justice system as whole and efficiency and competence of judges and prosecutors as holders of judicial functions.

Debate on results of reform activities is still ongoing in professional public. Implementation of 2006 Strategy brought following changes:

Significant changes to the legislative framework of the Serbian judiciary have been enacted for over the last ten years. Changes to the Constitution and the laws governing the judiciary have enshrined the principles of judicial independence, accountability, and transparency in the legislative framework.

Numerous major institutional changes were also implemented: these include the successful establishment of specialized courts for organized crime and war crimes at the beginning of the decade and the later establishment of the Judicial Academy. More recent changes, such as strengthening the mandates of the High Judicial Council and State Prosecutorial Council, have yet to be successfully implemented. 


\section{Key constraints to reform design and implementation} have included the lack of political consensus on the direction of reforms and conflicts over the division of labour between the parliament, executive, and judiciary on the appointment-and recently the reappointment-of judges and prosecutors.

In 2009, all judges and prosecutors were required to reapply for their positions, and many incumbents were not selected. The change in the composition of the judiciary went beyond purging judges and prosecutors implicated in criminal activity, created significant controversy and has disrupted judiciary operations. Based on the decision of the Constitutional Court all non-re-elected judges and prosecutors were returned to the system (lack of objective criteria and transparent procedure for their non-re-election was the ground for the Constitutional complain).

One of the issues that is subject of debate is whether evaluation of prosecutors is needed. Part of professional public is against introduction of evaluation of prosecutors work and performance since they believe that introduction of evaluation will diminish position of prosecutors and make it equal with the position of clerks. Other believes that it is necessary to introduce performance evaluation in order to enable objective and professional criteria for promotion. Few years ago overcame opinion that performance evaluation is necessity for improvement of efficiency and quality of justice system and regaining of citizens trust in judiciary.

\section{PERFORMANCE EVALUATION}

Individual judicial evaluations can provide prosecutors leadership with valuable feedback for judicial development and education, appropriate placement or promotion, needed improvements in the prosecutorial administration, resource allocation, and predicting workload trends. Until this time, evaluation of prosecutors has 
been guided by the Law on Public Prosecution from 2008. The Law called for regular evaluation based on publicized, objective, and uniform criteria, through a procedure ensuring the participation of the judge or prosecutor being evaluated. According to Law, the performance of prosecutors is evaluated once every three years, with performance of a first-time elected deputy public prosecutor evaluated annually for each of the first three years. Prosecutors may also be evaluated more frequently on an exceptional basis. In order to implement this legal obligation, the bylaw on Rules for performance evaluation was needed. However drafting and adoption of this Rules was a challenge for prosecution service and policy makers. Lack of the Evaluation Rules had as a result election on permanent function in December 2013 all deputy prosecutors who were first-time elected in December 2010. This situation open discussion if three-year probation period should be abolished.

Reason for delay in adoption of Rules could be fined in the fact that the Serbian judiciary historically lacked an objective entry point for the judicial profession, as well as performance evaluation. In theory, productivity norms existed for evaluating prosecutors, but they did not incentivize good behaviour and evaluations were not conducted comprehensively. Traditionally performance of prosecutors in Serbia was evaluated based on the number of resolved cases. By relying almost entirely on the number of dispositions per month, productivity norms encourage prosecutors to 'cherry pick' simple cases or resolve cases too quickly while avoiding complex cases. The only consideration of work quality was the rate of cases set aside on appeal, which may take some years to eventuate. Although productivity norms are no longer 'official', their continued existence creates a frame to guide the behaviour of individual prosecutors. The most determinative of whether individual prosecutor comply with productivity norms is whether their individual head of prosecution office monitors those norms. 
Influenced by the Venice Commission opinion and professional debate it was concluded that performance evaluation should be based on combination of statistical and qualitative indicators with the prevailing influence of qualitative. Serbian judiciary and experts faced with the challenge to develop comprehensive, objective, transparent and accepted by judiciary criteria for performance evaluation. First draft rules were prepared by the working group of the Association of prosecutors in 2008 supported by OSCE and EU expertise as well as by the regional experience. However it took six more years to adopt Rules on evaluation.

Test for performance evaluation of prosecutors were ad hoc Rules of procedure on criteria and standards for the evaluation of qualification, competence and worthiness of candidates for public prosecutors that were adopted in 2009 and were used for re-election of prosecutors. Main criteria were qualification ${ }^{4}$, competence $^{5}$ and worthiness ${ }^{6}$. Worthiness caused the biggest problem in practical implementation and was ground for non-re-election of prosecutors.

According to the Venice Commission opinion these Rules were very detailed, comprehensive and form a good basis on which to establish permanent objective criteria for the appointment and promotion of prosecutors. They provided for a concrete and objective evaluation of prosecutors, carried out by the State Prosecutorial Council, an authority that provides guarantees of impartiality and competence.

4 Qualification is established based upon: general expert knowledge and possession of particular knowledge which are of importance for performing the function of public prosecutor.

5 Competence is established based upon: demonstrated capability in application of expert knowledge and undertaking of procedural actions, demonstrated professional skill, analytical thinking, capability of opinion and decision making, skill in explanation of legal positions, quality of written and oral expression, communication skills, and capability for team work.

6 Worthiness is established based upon the reputation the candidate has in the professional surrounding, through his/her behaviour within the performance of public prosecutor's function and outside it. 
However main concerns of Venice commission were:

the risk of an over mechanistic approach to statistical information concerning workloads and the like, and

evaluating persons through the use of questionnaires by their colleagues which are filled anonymously posed risks that a prosecutor could be evaluated unfairly.

In addition, the evaluation procedure from the 2009 Rules required much work from the prosecutors and from the State Prosecutorial Council. Lack of capacity and dedication of staff for evaluation were one of the biggest obstacles to fair, objective and transparent re-election of prosecutors and implementation of Rules failed on their non-transparent application by the Council.

In 2011 the draft Rules for prosecutor evaluation were prepared by State Prosecutorial Council. Draft rules were specific about the competencies required of prosecutors. These included the capacity to apply professional knowledge, capacity to undertake process operations, analytic approach, capacity for judging and decision making, capacity to explain legal approaches, oral and written skills, and teamwork ${ }^{7}$.

Calculations of prosecutor performance are also highly complex, with many criteria to be considered. The criteria for evaluating prosecutors were:
Efficiency
Timely case resolution
Use of proper legal remedies
Written and oral skills; capacity to explain legal approaches
Adoption of new knowledge, professional education, and training
Cooperation with employees, court and other state organs, organizations, and participants.

The level of care and detail exercised in developing the

7 Proposal for Evaluation of Prosecutors, Article 4. 
evaluation proposals has not been extended to considerations of promotion of deputy prosecutors. The State Prosecutorial Council decides on the selection of deputy public prosecutors with tenure to another or higher office but the draft rules for evaluating prosecutors for promotion were not well developed, indicating for prosecutors, for example, only that public prosecutors and deputy public prosecutors awarded a rating of "exceptionally successful performance of public prosecutorial function", have priority for promotion ${ }^{8}$.

The proposed evaluation criteria for public (chief) prosecutors 9 reflects the large scope of responsibilities of the chief prosecutor. The performance evaluation of a public prosecutors conducted by the directly superior prosecutor ${ }^{10}$ after obtaining the opinion of the Collegium of the higher prosecutor's office. In evaluating performance, periodic reports on the work of the public prosecutor's office are taken into account. These include:

establishing promptness in the work of public prosecutions, general capacity to manage public prosecution, capacity to supervise, capacity to improve work of the public prosecutions, and risk management capacity.

Each term is defined carefully in the proposed rules.

\section{Rules for evaluation of prosecutors}

In May 2014 after several years of discussion and working documents State Prosecutorial Council adopted Rules on evaluation. Competence for the adoption of the Evaluation Rules has State Prosecutorial Council and legal basis is in the Law on the State Prosecutorial Council (2008) where it is said that the Council has the following duties:

8 Proposal for evaluation of prosecutors, Article 46.

9 Article 21.

10 Evaluation Procedure Article 102, Law on Public Prosecution. 
Elect deputy prosecutors to permanent position

Rule in the process of the performance evaluation of a deputy prosecutors and head of prosecutors' offices

Rule on legal remedies in disciplinary proceedings.

The Law gives the State Prosecutorial Council the right to pass such evaluation rules as legally binding law for all deputy prosecutors and chief prosecutors in Serbia. This right which Law gives to the SPC has its constitutional basis in (Article 165) the Constitution of the Republic of Serbia.

Rules for performance evaluation of prosecutors will be in the piloting phase from June 2014 till end of December 2014 in 5 prosecutors' offices in order to identify if there are some obstacles in implementation (complexity of criteria, lack of data, unclear definitions, etc) and to amend Rules before end of January when it is planned to enter into force in all prosecutors' offices. Results from this probationary period will not be included in personal files of deputy prosecutors and head of selected prosecutors' office. Rules for performance evaluation combines quantitative and qualitative criteria for evaluation.

Criteria for evaluation of deputy prosecutors are:

Promptness when proceeding ${ }^{11}$, Competence and success in work ${ }^{12}$ Professional commitment and cooperation ${ }^{13}$.

\footnotetext{
11 Promptness when proceeding is being evaluated based on standards, i.e. number of processed cases by a deputy public prosecutor compared to number of assigned cases in the period of evaluation of work.

12 Competence and success in work is being evaluated based on standards, i.e. share of valid convictions within total of valid both convictions and acquittals passed upon bills of indictment actioned by a deputy public prosecutor related to each person respectively in the period of evaluation.

13 Professional commitment and cooperation are being evaluated based on the following standards:

- quality of written and oral eloquence,

- precision and clarity of acts and undertaken procedural activities,

- skillfulness in elaboration of legal standpoints,

- responsibility when presenting legal acts,

- professional advancement and use of available information and communication technologies;

- respect for rights of personality and dignity of parties in proceedings,

- relation and cooperation with other prosecutors, employees in public prosecution office, court and other state bodies.
} 
Criteria for evaluation of public prosecutors (head of offices) are:

General ability to administer a public prosecution office ${ }^{14}$, Ability to monitor ${ }^{15}$,

Total performance results of the public prosecution office under his/her

management ${ }^{16}$.

Individual marks for criteria for evaluation of work of prosecutors are: "extremely successful", "successful", "does not satisfy". Quality of prosecutors work is evaluated based on number of confirmed judgments. It has to be seen in future period how this Rules will influence on performance of all prosecutors.

If in the period of evaluation of work of a deputy public prosecutor or a directly lower public prosecutor, a public prosecutor determines that there is a possibility that a prosecutor gets evaluated by the mark "does not satisfy", he is obliged to warn him about that in written form, with the elaboration and suggestion of measures for elimination of the noted omissions in work.

14 General ability to manage public prosecution offices is evaluated based on standards:

1. able to organize material, organizational, financial, administrative and other tasks, to issue normative acts, provide security of data, ability to manage public prosecution office during crisis,

2. ability to determine tasks in the public prosecution office work, ability to motivate prosecutors and other employees to realize goals and tasks;

3. achievement of conditions for use of efficient methods and technical resources in administrative operations; ability to guide employees to use available and new information and communication technologies; 15 Ability to monitor is evaluated based on standards:

1. ability to achieve control of work of a lower public prosecutor, a deputy public prosecutor and the employees in a public prosecution office, readiness to provide instructions and advice to lower public prosecutors, deputy public prosecutors, prosecutorial assistants and trainees;

2. monitoring of complex cases, influence to penal policy, accurate and timely decision making on objections and complaints to work of a deputy public prosecutor and employees in the public prosecution office, responsibility for correct implementation of instructions of a higher public prosecutor, 3. ability to harmonize prosecutorial and court practice; ability to harmonize work and proceeding of a lower public prosecutor, a deputy public prosecutor, prosecutorial assistants and trainees when implementing laws and other regulations; undertaking measures with a view to enhance professionalism of the employees in the public prosecution office.

16 Overall performance results are evaluated based on standards - relation of number of assigned cases of the public prosecution office the public prosecutor is in charge of and number of processed cases in the period of evaluation of work. Individual mark is being determined based on average results from all annual performance reports written in the period of evaluation of work. Annual performance report expresses relation of number of assigned cases and number of processed cases that had been sent, at latest, 15 days after expiration of the reporting period. 


\section{RULES FOR ELECTION AND PROMOTION OF PROSECUTORS}

Draft criteria for election and promotion of prosecutors are in the phase of public discussion. Open issue is relation between evaluation of prosecutors and hierarchy of prosecutorial organization, especially in relation to obligatory instruction of higher prosecutor. Draft Rules on election and promotion envisaged performance evaluation based on assessment of the head of office and Collegium of all deputies from the office.

Open issue and subject for expert discussion is relation between performance evaluation and hierarchy of prosecutors. Having in mind that according to existing legislation and organization of prosecutorial service there is possibility of hierarchical intervention of the higher prosecutor in the case of lower prosecutor it is not clear how to evaluate those cases.

Higher prosecutor can issue instruction without taking over of a case. Also there is right of the Head of prosecution service (General Prosecutor) to issue obligatory general instruction and that right is exercised relatively often having in mind significant legislative reforms and need for interpretation and position taking.

Rules on promotion should build in positive incentives for judges to contribute to the judiciary's performance. Several modern judiciaries use promotion criteria as a way to incentivize good behaviour and signal the kinds of attributes that judges should develop if they seek career advancement. This is especially true for judiciaries that have a balanced age structure, because permanent younger judges need clear signal for career progression to maintain motivation and morale. 


\section{TRAINING OF PROSECUTORS - JUDICIAL ACADEMY}

The United Nations and the Council of Europe emphasize a close link between initial and in-service training of deputy prosecutors and the independence and efficiency of the judicial system. The Judicial Academy began operating in 2010, and provides initial training for judicial and prosecutor candidates, and continuing training for judges, prosecutors and court staff ${ }^{17}$. The Judicial Academy is the legal successor of the Judicial Training Centre that was established in 2001 with the aim to provide continuous training for judges and prosecutors.

To date, the Academy focused on providing initial judge and prosecutor training and internal functioning, while continuing training was conducted sporadically. Participants in the 30-month initial training program have coursework and have practical internships relating to civil law, criminal law, minor offences law, and the prosecution of cases. The High Judicial Council and the State Prosecutorial Council determine the number of trainees to be admitted to the Academy each year.

Candidates who successfully complete the initial training program have been given preference for appointments as judges or prosecutors in comparison to judicial assistance ${ }^{18}$. Introduction of new system for the election of prosecutors (as well as judges) did not envisage transitional period for judicial assistants who were already in the system fulfilling requirements for election on deputy prosecutor position. The Association of Judicial and Prosecutorial Assistants challenged constitutionality of the Law on the JA.

However, a February 6, 2014 decision of the Constitutional Court may mean the statutory preference for appointment of

17 Article 1, Law on Judicial Academy, Official Gazette of the Republic of Serbia, No. 104/2009. 18 The first generation of students who successfully completed the initial training program and passed their final exams were elected as judges and prosecutors in 2013. 
trainees from the JA may no longer be valid ${ }^{19}$. The Association of Judicial and Prosecutorial Assistants ${ }^{20}$, established in reaction to the preference given to JA graduates for judicial and prosecutorial appointments, over judicial and prosecutorial assistants who met the requirements for judges and prosecutors before the establishment of the JA.

Among the most significant aspects of Serbian judiciary reform are the enhanced requirements for prosecutor training by the Judicial Academy and the determination of training needs by the judiciary itself through the Program Council of the Academy ${ }^{21}$. This structure is closely aligned with the principles promulgated by the Council of Europe ${ }^{22}$. Funds for the Academy's work come largely from the republican budget, supplemented by donations and income from publications and projects ${ }^{23}$.

Initial and continuing training for deputy public prosecutors who were first selected before the training program came into being and who have not completed initial training are obligated to attend a special permanent training program ${ }^{24}$.

One of the requirements for the EU integration process related to the justice sector is introduction of objective and transparent criteria and procedure for entrance into the judiciary and way to do that is through the initial training of the Judicial Academy. In the Serbia Progress Report there is request that Academy should become single entry point for judges and prosecutors. However having in mind weaknesses of the institutional framework (Judicial Academy, State Prosecutorial Council and High Judicial Council) there

19 Articles 26-27, Law on Judicial Academy, Official Gazette of the Republic of Serbia, No. 104/2009. 20 In February 2014 the Association of Judicial and Prosecutorial Assistance split in two Associations since they have different views on possible solutions after decision of the Constitutional Court.

21 Comprised of 11 members (at least five judges, three public prosecutors, one staff member of a court or prosecutor's office, and training experts).

22 European Charter on the Statute for Judges, Independence of the Judiciary, item 7, principles I 1 and 2 b, Recommendations no R (94) 12 of the Committee of Ministers of the Council of Europe, 1.1.6. 23 Law on Judicial Academy, Article 22. The current state budget of the Academy is approximately US\$ 700,000.

24 Law on Judicial Academy, Article 45. 
is ongoing discussion in the professional public if Judicial Academy should be single entry point.

Beside initial training ongoing discussion, the Judicial Academy is facing continuous training challenge. In order to have strong Judicial Academy that is capable to provide various type of general and tailor made trainings, annual catalogue of training and to have competent human recourse capacity (both in house and pool of trainers) the Academy should not face with budget constraints.

\section{MANDATORY TRAINING AND PROMOTION}

Prosecutors are not obligated to attend continuing training except for few specific topics ${ }^{25}$, and there is little incentive for them to do so (see discussion of continuing training in promotion decisions). Courses in substantive areas such as civil, family, or labour law are not regularly offered as continuing training courses. Instead, continuing education centres on topics of immediate interest such changes in the new Criminal Procedure Code.

Training and evaluation of prosecutors are linked in the area of mandatory training for prosecutors who are rated as less than satisfactory. The Law on Judicial Academy provides that the councils may require judges or prosecutors to attend special training programs to remedy poor performance, but how this will be effectuated has not yet been articulated. The High Judicial Council and State Prosecutorial Council have not determined how to implement these provisions, so it is unclear whether remedial training will be pursued seriously and whether funding for remedial training is to be budgeted by the Academy or by the institution to which the judge or prosecutor is appointed.

Related to the promotion of prosecutors, professional commitment as criteria for performance evaluation of prosecutors is

25 For example, juvenile law if a prosecutor is assigned to these cases. 
evaluate based on indicator of professional advancement/training.

Development of successful training that meets requirement of the judiciary as well as performance evaluation is a long term goal.

\section{SYSTEM PERFORMANCE EVALUATION}

Serbia lacks system performance evaluation. Functional review of justice system prepared by the World Bank expert team is the first comprehensive assessment of all aspects of judiciary performance. The Review comprises an external performance assessment and an internal performance assessment. The external performance assessment examines how well the Serbian judicial system serves its citizens in terms of efficiency, quality, and access to justice services. The internal performance assessment examines the inner workings of the system, and how governance and management, financial and human resources, ICT, and infrastructure are managed for service delivery ${ }^{26}$.

Partial subsidy for system performance evaluation is evaluation of prosecutors as heads of prosecution offices since criteria for evaluation includes capability of prosecutors head to manage prosecutor office and work of deputy prosecutors. However evaluation of head of prosecutors' offices provides fragmented picture of individual office. Challenge for introduction of system performance evaluation will be monocratic system of prosecution organization.

Introduction of system performance evaluation will enable better governance and management of prosecutorial system not only of the carrier of individual prosecutor. To enable to introduce objective performance evaluation of individual prosecutor there is a need to know how system is functioning and what are the

26 The internal performance assessment (Part 2) is similar in structure and methodology to a Justice Sector Public Expenditure Review (JPER) or standard Functional Review. 
weaknesses and strengths of the system.

\section{DESAFIOS NO SISTEMA DE AVALIAÇÃO DE DESEMPENHO DE PROCURADORES}

\section{RESUMO}

Uma série de reformas adotadas na última década refletem diferentes pontos de vista de como o sistema judicial, e em particular os procuradores, devem ser gerenciados. Em 2000, as mudanças democráticas foram seguidas por iniciativas de reforma judicial, definidas como uma das prioridades do governo naquele momento. Muitas dessas atividades de reforma estão ligadas ao processo de integração da UE e ao cumprimento das normas da UE e do Conselho da Europa relacionadas com o sistema judiciário. A abordagem, a metodologia e o calendário das reformas judiciais são estabelecidos nos dois documentos estratégicos de cinco anos; Primeiro período coberto 2006-2011 e segundo é para o período 2013-2018. A Estratégia Nacional de Reforma Judicial 20132018 estabeleceu os seguintes objetivos: independência, imparcialidade e qualidade, competência, responsabilidade e eficiência. Ambos os documentos estratégicos definem um conjunto de medidas e indicadores para melhorar a eficiência e a competência do sistema de justiça no conjunto e a eficiência e competência dos juízes e procuradores como detentores de funções judiciais. O debate sobre os resultados das atividades de reforma ainda está em andamento no público profissional.

Palavras-chave: Sistema de Avaliação dos Procuradores. Eficiência. 


\section{REFERENCES}

EUROPEAN UNION. European Charter on the statute for judges. Strasbourg, Disponível em: < http://www.judicialcouncil.gov.az/Law/echarte.pdf>.

SERVIA. REPUBLIC OF. Law on Judicial Academy, Official Gazette of the Republic of Serbia, No. 104/2009. 